\title{
Impact of School Health Education on Prevalence of Dengue Fever in Lucknow City, India
}

\author{
Ramesh Chandra', Shaukat Kamal', SM Singh', Ashish Kumar', Rahul Kumar Singh', \\ SN Sharma', KK Mittra'
}

${ }^{1}$ Regional Office of Health \& Family Welfare, Govt. of India, Kendriya Bhawan, $9^{\text {th }}$ Floor, Aliganj, Lucknow, India. ${ }^{2}$ National Centre for Disease Control, MOH \& FW, Govt. of India, 22, Sham Nath Marg, Delhi, India.

DOI: https://doi.org/10.24321/0019.5138.202125

\section{I $\quad \mathbf{N} \quad \mathbf{F} \quad \mathbf{O}$}

\begin{abstract}
Corresponding Author: Floor, Aliganj, Lucknow, India.

E-mail Id:

shaukatkamal25@yahoo.in

Orcid Id:

How to cite this article: 53(2): 52-56.

Date of Submission: 2021-03-11

Date of Acceptance: 2021-06-o8
\end{abstract}

Shaukat Kamal, Regional Office of Health \& Family Welfare, Govt. of India, Kendriya Bhawan, $9^{\text {th }}$

https://orcid.org/0000-0002-3358-1572

Chandra R, Kamal S, Singh SM, Kumar A, Singh RK, Sharma SN, Mittra KK. Impact of School Health Education on Prevalence of Dengue Fever in Lucknow City, India. J Commun Dis. 2021;

\section{$\begin{array}{llllllll}\mathbf{A} & \mathbf{B} & \mathbf{S} & \mathbf{T} & \mathbf{R} & \mathbf{A} & \mathbf{C} & \mathbf{T}\end{array}$}

Of the six vector-borne diseases prevalent in the country, dengue is the second largest cause of morbidity and mortality. The disease is widely prevalent in all parts of the country with variation in intensity including Uttar Pradesh, the largest state of India. Though the disease is known to be urban in nature, cases are being reported from rural areas too. Uttar Pradesh experienced a statewide outbreak of dengue in 2016 and reported 15033 cases and 42 deaths, of which 2772 cases ( $18.44 \%$ of the state) and 18 deaths ( $42.86 \%$ of the state) occurred in the district of Lucknow. The disease is tackled under the guidelines of the Directorate of the National Vector Borne Disease Control Programme (NVBDCP). Accordingly, source reduction and prevention from mosquito bites are the most important techniques in order to prevent the disease spread. Various means like pamphlets and posters containing signs and symptoms of the disease including source reduction and prevention from mosquito bites, written in simple language (Hindi), video clips etc. were used as health educational material. Selected secondary/ junior schools were visited as per daily schedule during the month of July in 2017 and 2018, respectively. The sensitisation of the school children played a significant role in bringing down dengue morbidity by $83.73 \%$ and $74.74 \%$ and mortality by $88.89 \%$ and $94.44 \%$, during 2017 and 2018, respectively in comparison to 2016, whereas the case fatality rate (CFR) declined from $0.65 \%$ in 2016 to $0.14 \%$ in 2018 , as the school children along with their teachers played an important role in sensitisation towards the prevention of dengue, due to which they not only became actively involved but also communicated the required messages pertaining to the elimination of breeding sites and prevention from mosquito bites.

Keywords: Dengue, Chikungunya, Zika Outbreak, Surveillance, Arboviruses, Aedes aegypti, Intervention Measures, Source Reduction 


\section{Introduction}

Dengue, chikungunya, yellow fever and Zika are the diseases caused by arboviruses of different types. All of these are transmitted in human beings by a mosquito of a very sophisticated and aristocratic nature, known as tiger mosquito, Aedes aegypti. Yellow fever and Zika have not been reported in the state but there is a risk of these diseases. This mosquito vector is highly anthropophilic and a day biter, feeding on human beings to meet out its biological need, in multiple attempts from many persons (split feeder). Dengue fever is described as an emerging disease in India ${ }^{1}$ with initial cases reported by the end of the 20th century. The vector resulted in the focal outbreak of dengue among the susceptible and non-immune population of the urban area of district Shahjahanpur in $1993^{2}$ and the urban areas of some districts ${ }^{17-18}$ in the beginning of the 21 st century. The vector Aedes aegypti is widely spread in the tropical region including the Indian sub-continent. By the end of the second decade, it had gradually spread in all 75 districts of U.P. with numerous dengue cases reported. in 2019. Aedes albopictus is also widely distributed in India including Uttar Pradesh and similar to Aedes aegypti, it aids in the transmission of dengue and chikungunya.

Aedes aegypti is a container breeder and breeds in fresh water stored in containers in domestic and peri-domestic premises. Even a small disposed plastic cups with rain water collection, makes the most congenial conditions. Aedes albopictus breeds in fresh water marshy land, flower pots and even plant leaf axils. The occurrence of dengue fever and chikungunya are closely associated with the rainfall in the northern part of India including Uttar Pradesh ${ }^{20}$ but does not correlates with rainfall in the peninsular part of the country. Uttar Pradesh experienced a statewide outbreak of dengue in 2016 and reported 15033 dengue cases and 42 deaths, of which 2772 cases and 18 deaths were contributed by Lucknow. Thus, the contribution of Lucknow alone remained nearly one fifth $(18.44 \%)$ to the state's dengue cases and nearly half $(42.86 \%)$ to the total deaths due to dengue. The state enacted an 'Epidemic Act' during 2016 for prevention and control not only from dengue but from all vector-borne diseases. ${ }^{20}$ The outbreaks of dengue were also reported from other states both in urban and rural areas ${ }^{3-7}$ and regular entomological surveillance was recommended to prevent impending outbreaks ${ }^{1,8-14}$ along with health education to the community. Various studies suggested that youngsters in the school-age group, are affected more by the disease $\mathrm{e}^{9,18}$ and each gender in equality ${ }^{17}$ require to be provided massive health education, even vectorborne disease basic information to be incorporated in the educational curriculum. ${ }^{8}$ Keeping in view the severity of the situation of dengue in Lucknow and bionomics of the vector, it was thought of utmost importance to involve the community to take the responsibility of not creating breeding sites of Aedes aegypti and if already present, then eliminate them immediately Besides eliminating dengue vector, such interventions done in accordance with the NVBDCP guidelines will also help in the elimination of the vectors of chikungunya, yellow fever and Zika. The objective of the activity study was.

- To educate children and teachers about causative agent and transmission of dengue/chikungunya through mosquitoes.

- To educate the children and teachers regarding various breeding places of the dengue/chikungunya vector and possible methods of the prevention and control of their breeding.

- To educate the students and teachers regarding various methods for the prevention of vector bites to minimise the risk of dengue/chikungunya transmission in urban localities to ensure requisite behavioural practices.

The impact of such a coordinated action of school children among the community, on the occurrence of dengue in the years 2017 and 2018 has been presented in this article.

\section{Methodology}

An attempt was made by the Regional Office of Health \& Family Welfare (ROH \& FW), Lucknow to educate the students through their schools regarding prevention and control of dengue fever in Lucknow city. Therefore, all major schools were selected and covered in this study. Pamphlets and posters containing signs and symptoms of the disease including prevention from mosquito bites, written in simple language (Hindi) were used as health educational material (Figure-1). These schools were visited as per the daily schedule during the July month of 2017 and 2018. The Principals and senior teachers of the schools were first sensitised and briefed about signs and symptoms of the disease and the methods of its prevention and control. Pamphlets and posters with 'Dos \& Don'ts dos' were provided to the school principals and they were requested to display one poster/ pamphlet on the notice board/ prominent place of the school premises/class rooms. The principals were also requested to ask the students to follow the standard dress code and instruct them to attend the school only in full sleeves dress - an important step ordered by the local district administration. Another pamphlet was given with the request to make an announcement through the morning assembly of the schools regarding the prevention and control of dengue/DHF. Some of these schools photocopied these pamphlets/posters and pasted them in all the classrooms of the school for the individual attention of the students. Two video clippings were also made available on the WhatsApp of the Principals or any other senior teacher directed by them and they were requested to show video clips from prevention of dengue/ 
chikungunya and even other VBDs viz. malaria through audio-visual aids available in the schools. The students took a pledge against dengue mosquitogenic conditions. Our team member also joined in the morning assembly of some of the schools for creating awareness about the prevention and control of dengue. The larvae/ pupae of the Aedes mosquito collected during the area survey, were demonstrated to the teachers and students. The Regional Science Centre, Lucknow in collaboration with State Science \& Technology Department organised competitive activities of secondary schools pertaining to prevention from dengue, viz. painting, slogan writing, essay writing etc, in 2018 prior to transmission season of dengue. The expert judge for these activities were the team members from the Regional Office of Health \& Family Welfare, Govt. of India, Kendriya Bhawan, Lucknow. The data collected so, was analysed statistically and presented in this article.
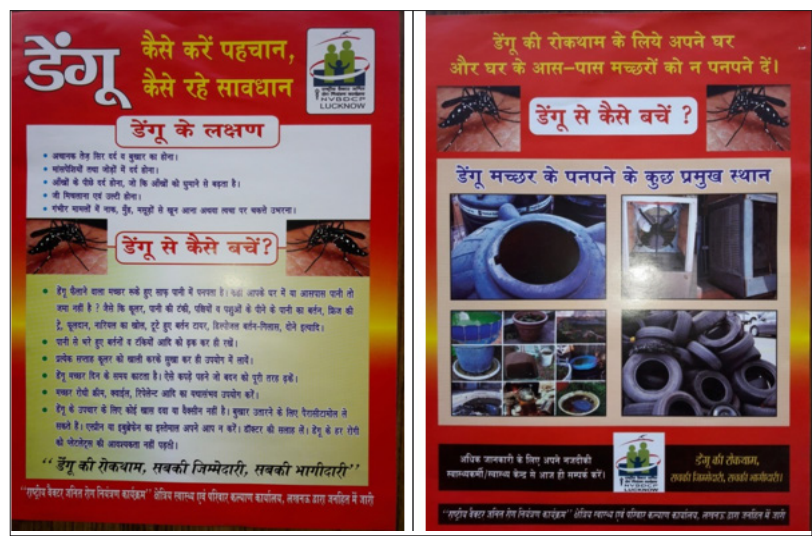

Figure I.Pamphlets used for display on school/class rooms notice board

\section{Results and Discussion}

The areas of the city in which school were visited include, Aliganj, Mahanagar, Nishatganj, Hazratganj, Indira Nagar, Vikas Nagar, Gomati Nagar, Chowk, IIM and Jankipuram (Table 1). The education authorities were requested to implement the use of full sleeves dress code by the students in order to cover up maximum body parts.

After the sensitisation meeting with the principals of schools, follow up visits were also made to some of the schools. It was found that these schools had displayed the pamphlets/ posters on the notice board and had made announcements in the morning assembly of school. Children responded to video clips shown to them in school and assured to behave in the source reduction direction by eliminating water containers in and around houses.

The state govt. had identified a nodal teacher in each basic/ junior school, who would organise various health-related activities in their schools including prevention and control of VBDs. These nodal teachers of Lucknow district having urban settings, were imparted half day orientation training in prevention and control from Vector-borne Diseases including dengue/chikungunya during 2018 (Table 2).

The health authorities of Lucknow are being advised to review the work performed by these teachers during the current year in generating awareness among students. The present step opted, was a small attempt to create awareness among school students for the prevention of dengue/chikungunya in Lucknow City. It is worth mentioning here that the missionary schools were not supportive to the extent of expectations. Many of them wasted the team's time in granting permission for meeting or entry into the school premises.

The vector surveillance for Aedes aegypti conducted in different areas for immature stages demonstration to the students/ teachers, while making visits to the schools, clearly indicates the presence of immature stages (Table 3), which were not significantly different in the areas surveyed. The indices calculated are though below critical level, yet the need to initiate the intervention activities and continued monitoring to keep a check on the spread in the geographical proportion not be ignored.

The effort by ROH \& FW, Lucknow was well supported and appreciated by the school authorities and local health authorities \& administration. There was no scale for measuring the impact of the activities collectively carried out by the teachers, students and community in eliminating the breeding sources of the vector and preventing themselves from the mosquito bites during two consecutive years but it can be assessed from the drastic decline in dengue morbidity by $83.73 \%$ and $74.74 \%$ and in mortality by $88.89 \%$ and $94.44 \%$, during 2017 and 2018, respectively, after a severe outbreak of dengue during 2016 (Table 4). Moreover, the case fatality rate (CFR) declined from $0.65 \%$ in 2016 to $0.14 \%$ in 2018 . This achievement can be attributed more to the activities performed by the active participation of the community in reducing the breeding sources and preventing mosquito bites, as a result of updated and timely awareness generation on initiation of the future generation's call, having affinity to the older generation rather than the development of immunity, which is of very short duration.

Table I.Numbers of Teachers/Students sensitised for Dengue/Chikungunya in Lucknow

\begin{tabular}{|c|c|c|c|c|}
\hline S. No. & Year & No. of Sec./Jr. Schools visited & No. of Students sensitized & No. of Nodal Teachers sensitized \\
\hline 1. & 2017 & 27 & 53095 & 56 \\
\hline 2. & 2018 & 36 & 59975 & 75 \\
\hline
\end{tabular}


Table 2.Number of Nodal Teachers of Basic Schools of District Lucknow responsible for imparting Health Education to Students in their Schools, oriented in prevention and control of Dengue/Chikungunya

\begin{tabular}{|c|c|c|c|}
\hline S. No. & Name of Block & Date of Orientation & No. of Teachers Trained \\
\hline 1. & Chinhat & & 200 \\
\hline 2. & Gosainganj & & 184 \\
\hline 3. & Kakori & & 201 \\
\hline 4. & Maal & \multirow{2}{*}{ 12th to 24th } \\
\hline 5. & July, 2018 & 171 \\
\hline 6. & Mohalihabad & & 173 \\
\hline 7. & Sarojini Nagar & & 240 \\
\hline 8. & Lucknow Urban & & 204 \\
\hline & TOTAL & & 131 \\
\hline
\end{tabular}

Table 3.Surveillance of Aedes Mosquito in Civil Area of Lucknow City in July, 2018

\begin{tabular}{|c|c|c|c|c|c|c|c|c|}
\hline $\begin{array}{c}\text { S. } \\
\text { No. }\end{array}$ & $\begin{array}{c}\text { Name of } \\
\text { the Locality } \\
\text { Surveyed }\end{array}$ & $\begin{array}{c}\text { Total Number } \\
\text { of Localities/ } \\
\text { Houses } \\
\text { Searched }\end{array}$ & $\begin{array}{c}\text { Number of } \\
\text { Localities / } \\
\text { Houses found } \\
\text { Positive }\end{array}$ & $\begin{array}{c}\text { House/ } \\
\text { Locality } \\
\text { Index (HI) }\end{array}$ & $\begin{array}{c}\text { Number of } \\
\text { Containers } \\
\text { Searched }\end{array}$ & $\begin{array}{c}\text { No. of } \\
\text { Containers } \\
\text { found Positive }\end{array}$ & $\begin{array}{c}\text { Container } \\
\text { Index (CI) }\end{array}$ & $\begin{array}{c}\text { Breteau } \\
\text { Index } \\
\text { (BI) }\end{array}$ \\
\hline 1. & $\begin{array}{c}\text { Farrukhabad } \\
\text { Chillawan }\end{array}$ & 57 & 02 & 03.50 & 131 & 04 & 03.05 & 07.02 \\
\hline 2. & $\begin{array}{c}\text { Gomati } \\
\text { Nagar }\end{array}$ & 88 & 06 & 06.81 & 136 & 11 & 08.09 & 12.50 \\
\hline 3. & Aliganj & 67 & 04 & 05.97 & 83 & 06 & 07.22 & 08.96 \\
\hline 4. & Hazratganj & 56 & 03 & 05.36 & 72 & 04 & 05.56 & 07.14 \\
\hline & Total & 268 & 15 & 5.597 & 422 & 25 & 5.92 & 9.32 \\
\hline
\end{tabular}

Table 4. Year-wise Dengue Cases \& Deaths in Lucknow, Uttar Pradesh, India

\begin{tabular}{|c|c|c|c|c|}
\hline S. No. & Year & Dengue Cases & Deaths due to Dengue & CFR (\%) \\
\hline 1. & 2016 & 2772 & 18 & 0.65 \\
\hline 2. & 2017 & 451 & 02 & 0.44 \\
\hline 3. & 2018 & 700 & 01 & 0.14 \\
\hline
\end{tabular}

\section{Conclusion}

On the basis of results and discussion, it can be concluded that the children of schools along with their teachers can play an important role if, sensitised towards the preventable diseases properly, due to which they will not only involve themselves but will communicate proper messages to the community pertaining to prevention from mosquitoborne diseases. This is clearly evident in the study as dengue morbidity was reduced by $83.73 \%$ and $74.74 \%$ and mortality by $88.89 \%$ and $94.44 \%$, during 2017 and 2018, respectively, whereas the case fatality rate (CFR) declined from $0.65 \%$ in 2016 to $0.14 \%$ in 2018 . Thus, the impact obtained clearly supports the inclusion of basic information on vector-borne diseases such as malaria, dengue etc and their prevention, in the educational curriculum at the primary/secondary education level. Besides this, 'Civic Bye-laws' may be framed and implemented effectively by the local bodies for taking action against the creators of mosquitogenic conditions, in lieu of the Govt. of Uttar Pradesh, Urban Development Department directions issued in November, 2016. ${ }^{21}$ The Medical \& Health department may regularly monitor the progress done by the education \& urban development department along with the other departments that contribute to the vector-borne disease problem.

\section{Acknowledgement}

The authors are thankful to the State Vector Borne Disease Programme Officer, Directorate General of Medical \& Health Services, Lucknow (UP) and District Malaria/VBD Officers/Health authorities of districts and Uttar Pradesh 
State for their inputs and support rendered for completing the present task. Thanks are also due to Dr. Anil Kumar, ex-Scientist F, I.C.M.R, Govt. of India, for their useful suggestions and statistical analysis.

\section{Conflict of Interest: None}

\section{References}

1. Sharma S N, Raina V K, Kumar A. Dengue/DHF: An emerging disease in India. J Commun Dis.2000;32(3):1759. [PubMed] [Google Scholar]

2. Jamal Uddin M, Jalees S, Sharma R S, Verghese T. Dengue Fever/Dengue Haemorrhagic Fever outbreak in Shahjahanpur, Uttar Pradesh. Dengue News Letter, 1993; 18: 2.

3. Khera A, Sharma RS. Epidemiological investigation of an outbreak of dengue fever in Malikpur village, under Najafgarh block, Delhi, 1992. Dengue News Letter, 1993; 18: 2.

4. Jamaluddin M, Saxena VK. First Outbreak of Dengue Fever in a typical rural area of Haryana State in northern India. J Commun Dis. 1997;29(2):169-70. [PubMed] [Google Scholar]

5. Kamal S, Jain S K, Patnaik S K, Lal S. An Outbreak of Dengue Fever in Veerannapet village, Cherial Mandal, of Warrangal District, Andhra Pradesh. J Commun Dis. 2005;37(4):301-6. [PubMed] [Google Scholar]

6. Baruah K, Singh PK, Mohalia MM, Dhariwal AC. A Study on Dengue Outbreak during 2009 in Bhopal and Indore Districts of Madhya Pradesh, India. J Commun Dis. 2010;42(4):273-9. [PubMed] [Google Scholar]

7. Norman G, Theodre A, Joseph A. An insular outbreak of Dengue Fever in a Rural South Indian Village. J Commun Dis. 1991;23(3):185-90. [PubMed] [Google Scholar]

8. Gupta P, Kumar P, Aggarwal OP. Knowledge, attitude and practices related to dengue in rural and slum areas of Delhi after the dengue epidemic of 1996. J Commun Dis. 1998;30(2):107-12. [PubMed] [Google Scholar]

9. Kaul SM, Sharma RS, Sharma SN, Panigrahi N, Phukan PK. Lal S. Preventing Dengue /Dengue Haemorrhagic Fever outbreaks in National Capital Territory of DelhiThe role of entomological surveillance. J Commun Dis. 1998;30(3):187-92. [PubMed] [Google Scholar]

10. Sharma SK, Pradhan K, Rath Y, Subba Rao SK. Observations on the Breeding Habit of Aedes Species in the Steel Township, Rourkela. J Commun Dis. 2001;33(1):28-35. [PubMed] [Google Scholar]

11. Kumar RR, Kamal S, Patnaik SK Sharma RC. Breeding habitats and Larval Indices of Aedesaegypti (L) in Residential Areas of Rajahmundry Town, Andhra Pradesh. J Commun Dis. 2002;34(1):50-8. [PubMed] [Google Scholar]

12. Kamal S, Patnaik SK, Sharma SK, Rao JS. A Study on the Breeding Habitats of Aedes Species around
Visakhapatnam Sea Port. J Commun Dis. 2003;35(1):525. [PubMed]

13. Balkrishnan N, Venkatesh S, Lal S. An entomological study on the Dengue vectors during outbreak of Dengue in Tiruppur town and its surroundings, Tamil Nadu, India. J Commun Dis. 2006;38(2):164-8. [PubMed] [Google Scholar]

14. Katyal R, Mathur KK, Kumar K, Das BP, Saxena VK, Lal $\mathrm{S}$, Kumar S. Risk factors involved in the transmission of Dengue/DHF in some selected localities of Jaipur (Rajasthan), India. J Commun Dis. 2011;43(1):81-3. [PubMed] [Google Scholar]

15. Prakash V, Patel S, Bhan S, Thomas TG. Vector Surveillance for Dengue, Chikungunya, Zika Virus and Yellow Fever at Three Blocks of Pakur Districts of Jharkhand, India. J Commun Dis. 2020;52(4):77-80. [Google Scholar]

16. Duthade MM, Bhakare JK, Damle AS. Clinical profile of Dengue Haemorrhagic Fever from Jan 2009 to Dec 2009 in and Around Aurangabad. J Commun Dis. 2011;43(2):131-4. [PubMed] [Google Scholar]

17. Kumar M, Verma RK, Mishra B. Prevalence of Dengue Fever in Western Uttar Pradesh, India: A Gender-Based Study. Int J Appl Basic Med Res. 2020;10(1):8-11. [PubMed] [Google Scholar]

18. Kumar M, Verma RK, Nirjhar S, Singh M. Dengue in Children and young adults, a cross sectional study from the western part of Uttar Pradesh. J Family Med Prim Care. 2020;9(1):293-7. [PubMed] [Google Scholar]

19. Shil P. Rainfall and dengue occurrences in India during 2010-2016. Biomed Res J. 2019;6(2):56-61. [Google Scholar]

20. Bare Acts Live [Internet]. 'The Uttar Pradesh Prevention and Control of Malaria, Dengue, Kala-azar and any vector borne disease Regulations, 2016'. Govt. of Uttar Pradesh, Medical Department Order No. 1288/Sec5/V-2016-Mala-48-2016, 2016 Nov.9, pp 04. Available from: http:/ /www. bareactslive.com/ALL/up850.htm

21. 'Bye-laws for legal action against mosquitogenic conditions creators' मच्छरजनक स्थितियां पैदा करने वालों के विरूद्ध कानूनी कार्यवाही करने के लिए उपविधियां). Govt. of Uttar Pradesh, Urban Development Department Order No. 6433/ IX1-96 dated 7th November, 1996, p. 471-76. 